\title{
Economic analysis of green fodder crops for enhancing the dairy profitability in Punjab
}

\author{
Singh, V. P., ${ }^{1}$ 冈 Singh, H., ${ }^{2}$ Kaur, I., ${ }^{3}$
}

Received: 28.09.2020

Revised: 13.12.2020

Accepted: 13.01.2021

\begin{abstract}
The present study has been carried out in three agro-climatic regions of Punjab state, i.e. Sub mountainous, Central and South-Western regions for examining the economics of different green fodder crops and importance of green fodder in enhancing the dairy profitability. The study consisted of a total sample size of $\mathbf{1 2 0}$ farmers growing green fodder crops and keeping dairy animals. It was observed from the study that the profitability from important green fodder crops based crop cycle is a little bit higher (bajra + berseem $₹ 51,213$ ) than the traditional wheat-paddy crop rotation (₹ 49,005). It was found that proportion of green fodder in the cost of milk production was lower (12.12 per cent) if green fodder is home-produced compared to the market prices of green fodder (23.13 per cent). In this way, the expenditure on green fodder can be curtailed by about 13-14 per cent, which will curtail the overall cost of production of milk and enhance the productivity and profitability from milk production. A direct link between green fodder quantity and milk yield has been observed. Therefore, farmers need to motivated for enhancing the green fodder production for properly feeding the animals and further, they should try to increase the herd size so that higher profits from dairy farming can be realized.
\end{abstract}

Key Words: Market price, milk yield, profitability, variable cost, zone

\section{Introduction}

In the agricultural economy of India, the livestock sector play an important role (Bhutiani and Ahamad, 2019). The potential to reduce rural poverty can be higher with growth in the livestock sector than the crop sector (Mellor, 2004). About 28.40 per cent of agricultural GDP in India is presently contributed by livestock sector (Anon, 2019a), and this contribution is 38.77 per cent in Punjab state (Anon, 2019b). The milk yield levels of dairy animals in our country are lower than those in developed nations. There is an acute shortage of green, dry fodder and concentrates in our country. The deficiency of green fodder is 35 per cent (Anon, 2012). Any attempt towards enhancing green fodder availability would result in an increased margin of profits to livestock owners. The profitability of milk production mainly depends on the source of feed and fodder as this cost component constitutes about 70-75 per cent of the total variable cost of dairy farming. Green fodder, which accounts for about 44 per cent of the feed and fodder expenditure, is the essential

\section{Author's Address}

Department of Dairy Economics and Business Management, College of Dairy Science \& Technology, Guru Angad Dev Veterinary and Animal Sciences University, Ludhiana-141004 E-mail.: dhindsavp@gmail.com component of animal feed which helps to obtain an optimum level of milk productivity (Kaur et al., 2012). Hence, studying the economics of green fodder crops is of utmost importance, but there is a dearth of literature on this topic in the Punjab state. With this backdrop, the present study has been carried out to study costs and returns of production of green fodder and its share in the total cost of milk production in Punjab. The study will provide useful information to policy planners, future researchers and other concerned in the dairy sector.

\section{Material and Methods}

Punjab state comprises of three homogeneous agroclimatic regions, i.e. Sub mountainous, Central and South Western regions (Anon, 2014). The present study has been carried out in all these regions. One district from each regions having the highest fodder area was selected for the study purpose. Further, two blocks were selected from each of the selected districts in such a way that one is near to district headquarters and one away from it to represent two different scenarios. Further, a group of two-three villages was selected from each of the selected blocks. A total sample size of 120 fodder growers was selected with 20 farmers from each group of 
villages. Primary data was collected for the agricultural year 2016-17 using personal interview method with the help of a pretested schedule. The schedule included information on working capital (hired and family labour, owned and hired machinery, seed, manure, fertilizer, pesticides, irrigation, and other miscellaneous expenses), production data, price of inputs and outputs, the price paid by purchasers of green fodder. The data on the distribution of dairy animals, milk yield, feed and fodder charges, labour charges, miscellaneous charges etc. was also collected for calculating the economics from milk production.

For achieving the objectives of the study and drawing appropriate inferences, suitable statistical techniques (averages and percentages etc.) were used. The cost and returns of various fodder crops were presented in tabular format. For testing the difference between various regions, the technique of one way analysis of variance was used. The linear correlation coefficient was worked out to see the relationship between milk yield and quantity of green fodder fed. SPSS 20 software was used for carrying out the statistical tests.

\section{Results and Discussion \\ Comparative economics of fodder crops}

The comparative economics of various fodder crops in various regions of Punjab has been shown in Table 1. A perusal of table revealed that among the Kharif fodder crops, bajra fodder was observed to be the most economical fodder crop with the profit of ₹19645/acre followed by sorghum and maize with ₹ 19159/acre and ₹ 13933/acre, respectively. In a regions wise analysis, the highest profit of bajra was found to be in Central region with ₹ 20655/acre due to higher yield, for sorghum in South-Western zone with ₹ 19664/acre on account of higher yield and for maize fodder in Sub Mountainous zone with ₹ 14097/acre which was on account of lower variable cost. Among rabi season fodder crops, the profit was observed to be the highest in berseem, i.e. ₹ 31568/acre and the same was maximum in South Western region with ₹ 32819/acre on account of lower variable cost followed by Central zone (₹ 30957/acre). Next to berseem was oats fodder in rabi season with an overall profit of ₹ 19756/acre which was maximum in South-Western zone, i.e. ₹ 20925/acre on account of higher yield and gross returns followed by Sub Mountainous zone (₹ 18574 acre). The total variable cost of sorghum fodder crop was $₹ 11946 / \mathrm{ha}$, and its major component was human labour expenditure (Grover and Kumar, 2013). About two-thirds of the total production was sold directly to forwarding/commission agent.

\section{Comparative profitability of competing crops}

The comparative profitability of various competing crops in various regions of Punjab state has been shown in Table 2. A perusal of table showed that among the Kharif season crops, the paddy crop was found to be most profitable with ₹ 25971/acre followed by maize with ₹ 19573/acre. The profit of paddy was maximum in the Central region with ₹ 28119/acre followed by South Western region (₹ 26963/acre). The maize crop was cultivated in Sub Mountainous region only. Further, the profit from sugarcane which is an annual crop, was observed to be ₹ 46411/acre and this crop was cultivated only in Sub Mountainous zone. Among rabi season competing crops, the profit was maximum in capsicum crop, i.e. ₹ 46343/acre followed by ₹ 23034/acre for the wheat crop. The capsicum was cultivated in South-Western zone only. The profit of wheat crop was the highest in the Central region with ₹ 24966 /acre followed closely by ₹ 24729 /acre in South-Western zone. According to Grover and Kumar, 2012, the profitability of the paddy crop was about double than that of sorghum fodder crop. Berseem fodder crop had higher profit than sorghum, but it was less profitable than its competing crop wheat in rabi season. Kumar and Grover (2014) found that the variable cost of maize fodder crop was found to be ₹ 8948/ha which was less than maize (grain) crop during the season.

\section{Share of green fodder in cost of buffalo milk production}

Share of green fodder in cost of buffalo milk production in various regions of Punjab state has been presented in Table 3. A perusal of table revealed that in the summer season, the average quantity of green fodder fed per milch animal per day was $28.40 \mathrm{~kg}$ which was the highest in Sub Mountainous region with $33.90 \mathrm{~kg}$ followed by Central zone $(26.70 \mathrm{~kg})$ and South Western zone $(24.20 \mathrm{~kg})$. The quantity of green fodder fed to animals in different zones differed significantly. The cost of homegrown green fodder per milch 
animal per day basis was the highest in Sub and South Western zones with ₹ 15.90 and ₹ 14.13 Mountainous zone, i.e. ₹ 19.85 followed by Central respectively with an overall cost of ₹ 16.76 in

Table 1. Comparative profitability of various fodder crops in various regions of Punjab state (₹/acre)

\begin{tabular}{|l|l|l|l|l|l|}
\hline \multirow{2}{*}{ Particulars } & Kharif & Rabi \\
\cline { 2 - 6 } & Maize & Sorghum & Bajra & Berseem & Oats \\
\hline Sub Mountainous zone & 8082 & 9713 & 7418 & 18282 & 8916 \\
\hline Total Variable Cost & 171 & 214 & 209 & 409 & 212 \\
\hline Yield (q/acre) & 22179 & 27312 & 27023 & 48446 & 27490 \\
\hline Gross Returns & 14097 & 17599 & 19605 & 30164 & 18574 \\
\hline Profit & \multicolumn{5}{|l|}{} \\
\hline Central zone & 8440 & - & 7396 & 17437 & 8562 \\
\hline Total Variable Cost & - & 214 & 410 & 218 \\
\hline Yield (q/acre) & 22454 & - & 28051 & 48394 & 27054 \\
\hline Gross Returns & 14014 & - & 20655 & 30957 & 18492 \\
\hline Profit & 9005 & 9407 & - & 14970 & 7645 \\
\hline South Western zone & 174 & 224 & & 413 & 218 \\
\hline Total Variable Cost & 22144 & 29071 & - & 47789 & 28570 \\
\hline Yield (q/acre) & 13139 & 19664 & - & 32819 & 20925 \\
\hline Gross Returns & 8315 & 9464 & 7395 & 16648 & 8607 \\
\hline Profit & 173 & 221 & 211 & 410 & 216 \\
\hline Punjab & 22248 & 28623 & 27040 & 48216 & 28363 \\
\hline Total Variable Cost & 13933 & 19159 & 19645 & 31568 & 19756 \\
\hline Yield (q/acre) &
\end{tabular}

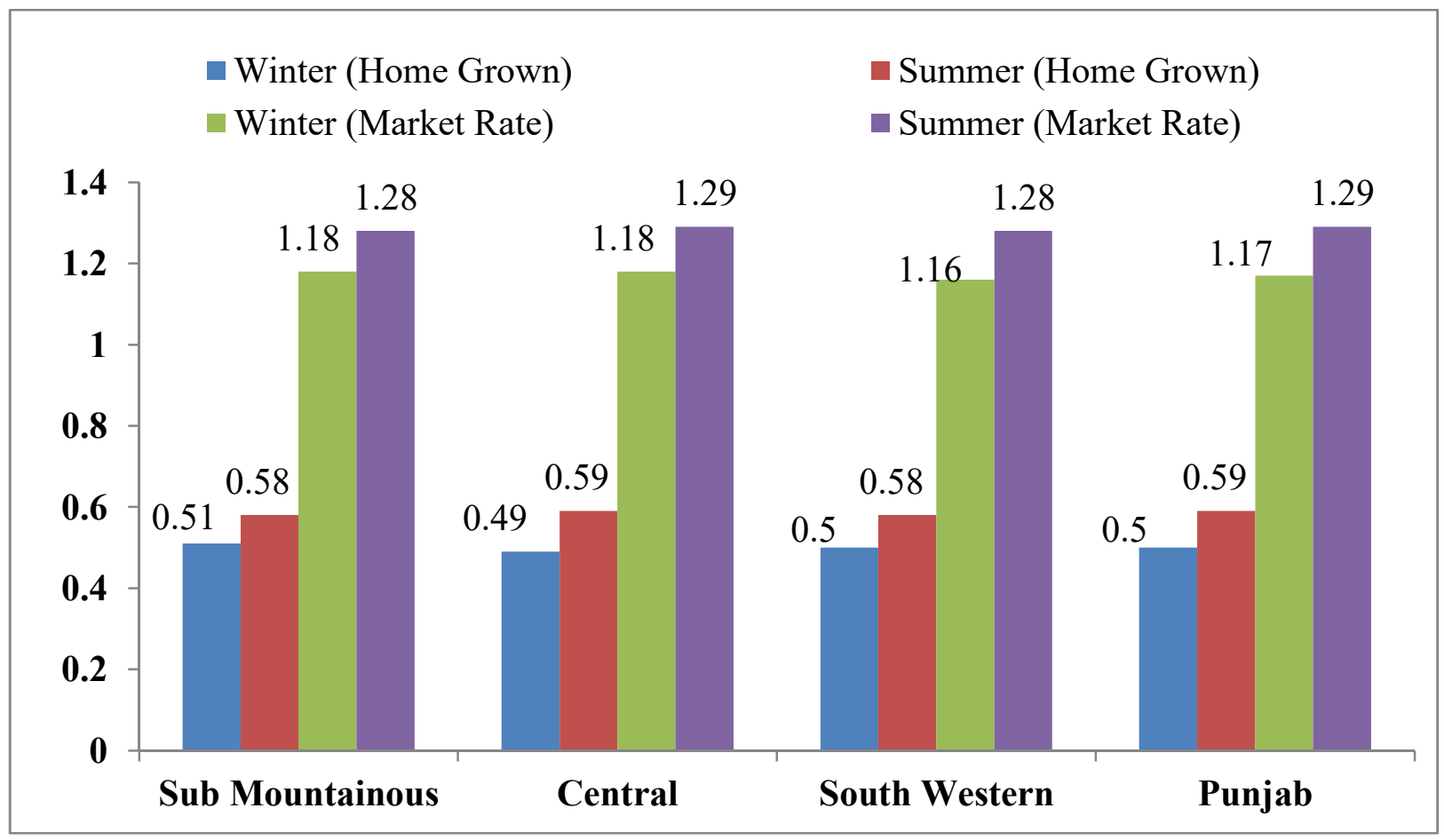

Figure 1. Price of home grown and market price of green fodder $(₹ / \mathrm{kg})$ 
Singh et al.

Table 2. Comparative profitability of various competing crops in various regions of Punjab state (₹ /acre)

\begin{tabular}{|l|l|l|l|l|l|}
\hline \multirow{2}{*}{ Particulars } & Kharif & Rabi & \multirow{2}{*}{ Sugarcane } \\
\cline { 2 - 5 } & Paddy & Maize & Wheat & Capsicum & \\
\hline Sub Mountainous zone & 19437 & 12794 & 11298 & - & 40239 \\
\hline Total Variable Cost & 39884 & 32367 & 30466 & - & 86650 \\
\hline Gross Returns & 20447 & 19573 & 19168 & - & 46411 \\
\hline Profit & \multicolumn{5}{l}{} \\
\hline Central zone & 19971 & - & 10692 & - & - \\
\hline Total Variable Cost & 48090 & - & 35658 & - & - \\
\hline Gross Returns & 28119 & - & 24966 & - & - \\
\hline Profit & \multicolumn{5}{|l}{} \\
\hline South Western zone & 20132 & - & 11109 & 48657 & - \\
\hline Total Variable Cost & 47095 & - & 35838 & 95000 & - \\
\hline Gross Returns & 26963 & - & 24729 & 46343 & - \\
\hline Profit & \multicolumn{7}{|l}{} \\
\hline Punjab & 19930 & 12794 & 10909 & 48657 & 40239 \\
\hline Total Variable Cost & 45901 & 32367 & 33943 & 95000 & 86650 \\
\hline Gross Returns & 25971 & 19573 & 23034 & 46343 & 46411 \\
\hline Profit
\end{tabular}

Table 3. Share of green fodder in cost of buffalo milk production in various regions of Punjab state (₹ /day/milch animal)

\begin{tabular}{|c|c|c|c|c|}
\hline Particulars/Zone & Sub-mountainous & Central & South -Western & Punjab \\
\hline \multicolumn{5}{|l|}{ Summer } \\
\hline Quantity of green fodder $(\mathrm{Kg})$ & $33.90^{\mathrm{a}}$ & $26.70^{b}$ & $24.20^{\mathrm{c}}$ & 28.40 \\
\hline \multicolumn{5}{|l|}{ Home grown fodder } \\
\hline Cost of green fodder & $19.85^{\mathrm{a}}$ & $15.90^{\mathrm{b}}$ & $14.13^{\mathrm{c}}$ & 16.76 \\
\hline Total variable cost & $128.28^{\mathrm{a}}$ & $125.87^{\mathrm{a}}$ & $105.26^{\mathrm{b}}$ & 119.39 \\
\hline Proportion of green fodder cost & 15.47 & 12.63 & 13.42 & 14.04 \\
\hline \multicolumn{5}{|c|}{ If green fodder is purchased from market } \\
\hline Cost of green fodder & $43.42^{\mathrm{a}}$ & $34.44^{\mathrm{b}}$ & $31.45^{\mathrm{b}}$ & 36.64 \\
\hline Total variable cost & $151.85^{\mathrm{a}}$ & $144.41^{\mathrm{a}}$ & $122.58^{\mathrm{b}}$ & 139.27 \\
\hline Proportion of green fodder cost & 28.59 & 23.85 & 25.66 & 26.31 \\
\hline \multicolumn{5}{|l|}{ Winter } \\
\hline Quantity of green fodder $(\mathrm{Kg})$ & $35.40^{\mathrm{a}}$ & $33.90^{\mathrm{a}}$ & $26.00^{\mathrm{b}}$ & 31.80 \\
\hline \multicolumn{5}{|l|}{ Home grown fodder } \\
\hline Cost of green fodder & $18.06^{\mathrm{a}}$ & $16.82^{\mathrm{a}}$ & $12.75^{\mathrm{b}}$ & 15.90 \\
\hline Total variable cost & $133.41^{\mathrm{a}}$ & $138.31^{\mathrm{a}}$ & $107.29^{b}$ & 125.87 \\
\hline Proportion of green fodder cost & 13.54 & 12.16 & 11.88 & 12.63 \\
\hline \multicolumn{5}{|c|}{ If green fodder is purchased from market } \\
\hline Cost of green fodder & $41.72^{\mathrm{a}}$ & $40.05^{\mathrm{a}}$ & $29.37^{\mathrm{b}}$ & 37.21 \\
\hline Total variable cost & $157.07^{\mathrm{a}}$ & $161.54^{\mathrm{a}}$ & $123.91^{\mathrm{b}}$ & 147.18 \\
\hline Proportion of green fodder cost & 26.56 & 24.79 & 23.70 & 25.28 \\
\hline
\end{tabular}

Note: Figures followed with different superscripts are significantly different $(p<0.05)$

Punjab. There was a significant difference in the Western and Central regions with 13.42 per cent cost of green fodder in all three zones. The share of and 12.63 per cent, respectively with an overall green fodder in total variable cost of milk value of 14.04 per cent in the state. Further, if the production was the highest in Sub Mountainous market price of green fodder prevailing in the region, i.e. 15.47 per cent followed by South respective zones is considered instead of the actual 
cost of production, then the proportion of green fodder in variable cost of producing milk was found out to be 26.31 per cent in the state which was the maximum in Sub Mountainous region (28.59 per cent) followed by 25.66 per cent in South Western region. Similarly in the winter season, the cost of homegrown green fodder on per milch animal per day basis was the maximum in Sub Mountainous region, i.e. ₹ 18.06 followed by Central and South Western region with ₹ 16.82 and ₹ 12.75 respectively with an overall cost of ₹ 15.90 in Punjab. The proportion of green fodder to the total variable cost of milk production was the highest in Sub Mountainous zone, i.e. 13.54 per cent followed by Central and South Western regions with respective figures of 12.16 per cent and 11.88 per cent with an overall value of 12.63 per cent in the state. Further, if the market price of green fodder prevailing in the respective zones is considered instead of the actual cost of production, then the proportion of green fodder in variable cost of producing milk was found out to be 25.28 per cent in the state which was the highest in Sub Mountainous zone (26.56 per cent) followed by
24.79 per cent in Central zone. Hence, the farmers should focus on self-sustenance in green fodder so as to avoid the high cost of purchased green fodder.

\section{Share of green fodder in the cost of cow milk production.}

Share of green fodder in the cost of cow milk production in various regions of Punjab state has been shown in Table 4. A perusal of the table revealed that in the summer season, the average quantity of green fodder fed per milch animal per day was $27.70 \mathrm{~kg}$ which was the highest in Sub Mountainous region with $35.20 \mathrm{~kg}$ followed by Central zone $(25.30 \mathrm{~kg})$ and South Western regions $(22.60 \mathrm{~kg})$.

The green fodder quantity fed to animals differed significantly in different zones. The cost of homegrown green fodder on per milch animal per day was the highest in Sub Mountainous zone, i.e. ₹ 20.73 followed by Central and South Western zones with ₹ 15.59 and ₹ 13.35 respectively with an overall cost of ₹ 16.37 in Punjab. There was a significant difference in the cost of green fodder crops in all three regions.

Table 4. Share of green fodder in cost of cow milk production in various zones of Punjab state (₹/day/milch animal)

\begin{tabular}{|c|c|c|c|c|}
\hline Particulars/Zone & $\begin{array}{l}\text { Sub } \\
\text { mountainous }\end{array}$ & Central & $\begin{array}{l}\text { South } \\
\text { Western } \\
\end{array}$ & Punjab \\
\hline \multicolumn{5}{|l|}{ Summer } \\
\hline Quantity of green fodder $(\mathrm{Kg})$ & $35.20^{\mathrm{a}}$ & $25.30^{\mathrm{b}}$ & $23.60^{\mathrm{c}}$ & 27.70 \\
\hline \multicolumn{5}{|l|}{ Home grown fodder } \\
\hline Cost of green fodder & $20.73^{\mathrm{a}}$ & $15.59^{b}$ & $13.35^{\mathrm{c}}$ & 16.37 \\
\hline Total variable cost & $151.0^{\mathrm{a}}$ & $138.3^{\mathrm{a}}$ & $117.0^{\mathrm{b}}$ & 135.1 \\
\hline Proportion of green fodder cost & 13.73 & 11.27 & 11.41 & 12.12 \\
\hline \multicolumn{5}{|c|}{ If green fodder is purchased from market } \\
\hline Cost of green fodder & $43.57^{\mathrm{a}}$ & $32.61^{b}$ & $29.64^{b}$ & 35.73 \\
\hline Total variable cost & $173.84^{\mathrm{a}}$ & $155.32^{b}$ & $133.29^{\mathrm{c}}$ & 154.46 \\
\hline Proportion of green fodder cost & 25.06 & 20.99 & 22.23 & 23.13 \\
\hline \multicolumn{5}{|l|}{ Winter } \\
\hline Quantity of green fodder $(\mathrm{Kg})$ & $36.80^{\mathrm{a}}$ & $30.50^{\mathrm{b}}$ & $24.70^{\mathrm{c}}$ & 30.60 \\
\hline \multicolumn{5}{|l|}{ Home grown fodder } \\
\hline Cost of green fodder & $18.73^{\mathrm{a}}$ & $15.11^{\mathrm{b}}$ & $12.49^{\mathrm{c}}$ & 15.30 \\
\hline Total variable cost & $152.0^{\mathrm{a}}$ & $144.5^{\mathrm{ab}}$ & $115.0^{\mathrm{b}}$ & 137.0 \\
\hline Proportion of green fodder cost & 12.32 & 10.46 & 10.86 & 11.17 \\
\hline \multicolumn{5}{|c|}{ If green fodder is purchased from market } \\
\hline Cost of green fodder & $41.99^{\mathrm{a}}$ & $35.97^{\mathrm{b}}$ & $28.38^{\mathrm{c}}$ & 35.80 \\
\hline Total variable cost & $175.26^{\mathrm{a}}$ & $165.36^{\mathrm{a}}$ & $130.89^{b}$ & 157.50 \\
\hline Proportion of green fodder cost & 23.96 & 21.75 & 21.68 & 22.73 \\
\hline
\end{tabular}

Note: Figures followed with different superscripts are significantly different $(\mathrm{p}<0.05)$ 
Singh et al.

Table 5. Effect of quantity of green fodder fed on milk yield

\begin{tabular}{|l|l|l|l|l|}
\hline \multicolumn{2}{|l|}{ Green fodder fed (kg) } & $\begin{array}{l}\text { Group 1 } \\
(<\mathbf{3 0} \mathbf{~ k g})\end{array}$ & $\begin{array}{l}\text { Group 2 } \\
(\mathbf{3 0 - 3 5} \mathbf{~ k g})\end{array}$ & $\begin{array}{l}\text { Group 3 } \\
(35 \text { kg and above) }\end{array}$ \\
\hline Buffalo & Milk yield (lt/day) & $6.51^{\mathrm{a}}$ & $7.04^{\mathrm{bb}}$ & $7.59^{\mathrm{b}}$ \\
\hline Cow & Milk yield (lt/day) & $10.69^{\mathrm{a}}$ & $11.53^{\mathrm{ab}}$ & $12.44^{\mathrm{b}}$ \\
\hline Correlation coefficient between milk yield and green fodder fed \\
\hline Buffalo & $0.33^{*}$ & \\
\hline Cow & $0.37^{*}$
\end{tabular}

Note: Figures followed with different superscripts are significantly different $(\mathrm{p}<0.05)$

* indicates statistical significant at $5 \%$ level of significance.

The proportion of green fodder to the total variable cost of milk production was the maximum in Sub Mountainous region, i.e. 13.73 per cent followed by South Western and Central regions with 11.41 per cent and 11.27 per cent, respectively with an overall value of 12.12 per cent in the state. Further, if the market price of green fodder prevailing in the respective zones is considered instead of the actual cost of production, then the proportion of green fodder in variable cost of producing milk was found out to be 23.13 per cent in the state which was the maximum in Sub Mountainous region (25.06 per cent) followed by 22.23 per cent in South Western region.

Similarly in the winter season, the cost of homegrown green fodder on per milch animal per day basis was the maximum in Sub Mountainous region, i.e. ₹ 18.73 followed by Central and South Western regions with $₹ 15.11$ and $₹ 12.49$ respectively with an overall cost of ₹ 15.30 in Punjab state. The proportion of green fodder to the total variable cost of milk production was the highest in Sub Mountainous region, i.e. 12.32 per cent followed by South Western and Central regions with 10.86 per cent and 10.46 per cent, respectively with an overall value of 11.17 per cent in the state. Further, if the market price of green fodder prevailing in the respective zones is considered instead of the actual cost of production, then the proportion of green fodder in variable cost of producing milk was observed to be 22.73 per cent in the state which was the highest in Sub Mountainous region (23.96 per cent) followed by 21.75 per cent in Central region. Since the feed cost accounted for more than sixty per cent of the total cost, providing good quality feeds and fodder in sufficient amounts will take a long way to the farming community in increasing the milk production. The green fodder and concentrate quantities were different for different her size category, whereas dry fodder quantity was the same for all size categories (Anbukkani, 2016). Brar et a,l 2017 observed that small-sized dairy farmers had losses in both the seasons while the mediumsized dairy farmers were having profits indicating dairy farming not profitable in small category dairy farms. Hence, the number of milch animals should be increased to six or more for earning reasonable profits. Hence, green fodder should be adequately produced by the dairy farmers themselves as per requirement, and there should be no dependence on the purchase of fodder from the market. In this way, the expenditure on green fodder can be curtailed, which will bring down the overall cost of production of milk and enhance the productivity on account of the feeding of the proper quantity of green fodder. Singh et al., 2018 concluded from their study that if the yield levels of fodder crops remain same, then the area under fodder crops will have to be increased from 8.95 lakh ha to 12.53 lakh ha to meet the fodder requirement. On the other hand, if the area is to be kept constant, then the yield level of fodder crops has to be increased to $899.08 \mathrm{q} / \mathrm{ha}$ instead of existing $642.22 \mathrm{q} / \mathrm{ha}$ to meet the fodder requirement. However, more emphasis should be on improving the yield levels as there is no scope of the increasing area under green fodder crops because the area available for cultivation has almost stagnated in the state.

Price of homegrown green fodder and market price of green fodder

Figure 1 shows the green fodder price of homegrown fodder and market rate of green fodder in both summer and winter seasons. For homegrown green fodder, in the summer season, the overall price was ₹ $0.59 / \mathrm{kg}$ which was higher 
than winter price, and it was the maximum in Central region (₹ $0.59 / \mathrm{kg}$ ) followed closely by Sub Mountainous region and South-Western region with ₹ $0.58 / \mathrm{kg}$ in each zone. Similarly, the green fodder price in Punjab in the winter season of homegrown fodder was ₹ $0.50 / \mathrm{kg}$ out of which maximum was in Sub Mountainous zone (₹ $0.51 / \mathrm{kg}$ ) and minimum in Central zone (₹ $0.49 / \mathrm{kg}$ ). Further, regarding the prevailing market prices of green fodder, in the summer season, the overall price was ₹ $1.29 / \mathrm{kg}$ which was higher than winter price, and it was maximum in Central region ( $₹ 1.29 / \mathrm{kg}$ ) followed closely by Sub Mountainous region and SouthWestern region with ₹ $1.28 / \mathrm{kg}$ in each zone. In the summer season, the overall market price of green fodder was ₹ $1.17 / \mathrm{kg}$, and it was maximum in Sub Mountainous and Central zones with ₹ $1.18 / \mathrm{kg}$ in each zone and minimum in South Western region (₹ $1.16 / \mathrm{kg}$ ). Hence, the dairy farmers should give due consideration to green fodder production in their annual cropping plan.

\section{Effect of quantity of green fodder fed on milk} yield

The effect of the quantity of green fodder fed on milk yield is shown in table 5. The farmers were divided into three groups based on the green fodder quantities fed to the animals and first group having quantity less than $30 \mathrm{kgs}$; the second group includes quantity between 30 and $35 \mathrm{kgs}$ and group third 35 $\mathrm{kgs}$ and above. For testing the difference in yield of three groups, the technique of one-way analysis of variance was used. There was a significant difference in milk yield of the first and third group. Further, the correlation coefficient between milk yield and quantity of green fodder fed was observed to be positive, and it was statistically significant. Hence, it may be inferred that higher quantities of green fodder should be fed to the milch animals for higher productivity, and there is a need for enhancing the production of green fodder by the farmers.

\section{References}

Anbukkani, P. 2016. Economic analysis of dairy farming in dry farming areas of Tamil Nadu. Indian Journal of Dairy Science, 69: 86-93.

\section{Conclusion}

From the foregoing discussion, it may be inferred that the profit from important green fodder crops based rotation ( $₹$ 51,213) was a little bit higher than the traditional wheat-paddy crop cycle (₹ 49,005). The expenditure on green fodder can be curtailed by about 13-14 per cent by homegrown fodder which will curtail the overall cost of producing milk and enhance the productivity and profitability from milk production. Further, the quantity of green fodder fed to the milch animals had a direct bearing on the milk productivity level. The milk yield was significantly higher for the animals which are fed higher quantities of green fodder as compared to underfed milch animals. Therefore, farmers should try to concentrate more on enhancing green fodder production to minimize the shortage of green fodder requirement and enhance dairy profitability. The surplus green fodder if any, can be sold in the market to earn income which is a little bit more compared to the competing crops. Hence, with proper management of green fodder production at own fields, the overall farm profitability can be improved.

\section{Acknowledgement}

The paper has been culled from the thesis entitled "Examining the profitability and marketing pattern of green fodder for sustainable dairy development in Punjab" submitted by second author Harparteet Singh to Guru Angad Dev Veterinary and Animal Sciences University, Ludhiana-141004 during 2017 under the guidance of first author Dr Varinder Pal Singh. The authors are thankful to the ViceChancellor, GADVAU, Ludhiana and Dean, College of Dairy Science and Technology, GADVASU, Ludhiana for providing necessary infrastructure and other support required for completion of the study.

Anonymous. 2012. Report of the working group on animal husbandry and dairying for five-year plan (2012-2017) Planning Commission, Govt. of India, New Delhi.

Anonymous. 2019a. Basic Animal Husbandry Statistics .2017. Department of Animal Husbandry, Dairying and Fisheries, Ministry of Agriculture, Government of India, New Delhi. 


\section{Singh et al.}

Anonymous. 2019b. Statistical Abstract of Punjab 2016. Economic Advisor to Government, Economic and Statistical Organization, Chandigarh.

Bhutiani, R. and Ahamad, F. 2019. A case study on changing pattern of agriculture and related factors at Najibabad region of Bijnor, India. In: Contaminants in Agriculture and Environment: Health Risks and Remediation. Edited by Vinod Kumar, Rohitashw Kumar, Jogendra Singh and Pankaj Kumar (ISBN: 978-81-942017-0-0). DOI 10.26832/AESA-2019-CAE-0158-018, pp 237-247.

Brar, R.S., Kaur, I., Singh, V. P. and Chopra, S. 2017. Economic Analysis of Milk Production by Small and Medium Sized Dairy Farmers in Punjab. Indian Journal of Economics and Development, 13: 382-391.

Grover, D.K. and Kumar, S. 2012. Economics of Production, Processing and Marketing of Fodder Crops in India. Agro Economic Research Centre Study No. 29, Punjab Agricultural University, Ludhiana.
Grover, D.K. and Kumar, S. 2013. Sorghum (fodder) cultivation in Punjab: An Economic Analysis. Agricultural Economics Research Review, 26: 55-62.

Kaur, I., Singh, V.P., Kaur, H. and Singh, P. 2012. Cost-benefit analysis of cow milk production in Punjab. Journal of Agricultural Development and Policy, 22: 67-74.

Kumar, S. and Grover, D.K. 2014. Maize fodder in Punjab: An economic analysis. Indian Journal of Agricultural Research, 48: 307-312.

Mellor, J. 2004 Agricultural growth and poverty reduction: The rapidely increasing role of small holder livestock, in V. Ahuja (ed) Livestock and Livelihoods: Challenges and opportunities for Asia in the emerging market environment, NDDB, Anand.

Singh, H., Singh, V.P. and Kaur, I. 2018 Availability of green fodder in various zones of Punjab state. Indian Journal of Economics and Development, 14: 383-387. 